\title{
The Problem of Buddhist Teaching in Vietnam - The Current Situation And Solutions
}

\author{
Dr. Cao Thi Minh Hong \\ Nun, Thich Dieu Tam, Chief of Office cum Head of International Buddhist Department of the North Central \\ Division of Nuns, Vietnam.
}

\begin{abstract}
\end{abstract}
Buddhism was born in India from the 6th century BC, in the condition of society divided by unequal caste system. Buddhism was born as the successor and continuation of famous religious and philosophical movements of ancient India and is considered as one of the social doctrines against injustice in contemporary society. Propagation of the Dharma is a noble and sacred duty of a Buddhist disciple, because the purpose of the Buddha's birth was for the benefit of the many, out of compassion for the world, for the happiness and wellbeing of gods and species. people. Therefore, the Buddha's teachings are a practical way of life, inseparable from human beings. If you do not bring the righteous Dharma to all sentient beings to inherit, then Buddhism has no benefit. Inherited sentient beings must rely on the messengers of the Tathagata to propagate.

Keywords: Dissemination of the Dharma, monks and nuns, Buddhism, the benefit of sentient beings.

DOI: $10.7176 / \mathrm{JPCR} / 54-04$

Publication date:September $30^{\text {th }} 2021$

\section{Preamble}

Prince Siddhartha (Shidartha) is the founder of Buddhism, he was born in 624 BC, belongs to the Sakya family, the son of King Tinh San King Da Na (Sudhodana) ruled the country of Kapila. Ve (Kapilavasu) of Central India at that time and Queen Ma Da (Maya). Although he lived in a royal life, he still recognized the suffering of life and the impermanence of the world, so he was determined to leave home to seek the way to find the cause of suffering and the method of eliminating suffering to solve it. escape from the cycle of birth and death. After many years of searching for teachers to learn the Way, he realized that their cultivation methods could not liberate people from suffering. Finally, he sat down to meditate under the Bodhi tree. After 49 days and nights of meditating, he attained the unsurpassed Way, attained the state of "Right and Right Enlightenment", known as Buddha Shakyamuni. The Buddhadharma is a fluid, flexible flow that does not limit itself in any framework, that is, it must be reasonable, contract body, contract time, contract land ... all to meet the requirements of each era. That is the unchanging spirit of Buddhism. Buddhist monks and nuns on duty to propagate the Dharma, "The Tathagata Tathagata, the Tathagata's Action," must make the Buddha Dharma more and more popular everywhere, in all ages, all walks of life.. happy vow to save sentient beings, that is the ultimate ideal of a Buddhist disciple.

\section{Research Methods}

We base on the methodology of dialectical materialism and historical materialism, together with the using basic research methods such as analysis - synthesis method, logical - historical method, interpretation - inductive method, comparison method, comparison, ... as well as inheritance of data. from published works of scientists.

\section{Research content}

\subsection{Duties and roles of monks and nuns in spreading the Dharma}

The main idea of Buddhism is to teach people to be good, have knowledge to build a good and happy life in the present. Buddhism does not recognize that there is a supreme being who governs people's lives, does not bless or cause harm to anyone, but in life each person must obey the law of cause and effect. Evil deeds must be retribution. Buddhism is also shown to be a progressive religion when it does not have a caste attitude. The preaching career is confirmed, the mission of preaching is considered a noble mission of the monastic. In any era, monks and nuns also adapted and harmonized with the human life in that period, so: "Buddhist Dharma is not separated from the world". If the 21 st century is the "century of religion", the role and responsibility of Buddhist monks and nuns will be heavier in guiding people to return to their inner self and stabilize their spiritual life. To fulfill their mission and inherit, monks and nuns need to update their knowledge and preach the Dharma in the context of modern society, so the goal of preaching the Dharma needs to be clearly oriented to meet the needs of believers. As a Buddhist, the promotion of the righteous Dharma is greatly influenced by the practice and effectiveness of Buddhist activities of monks and nuns. Monks and nuns are the central agents that help the Buddha's teachings spread everywhere, reaching many different audiences. Monks and nuns must have 
the strength to practice to contribute more intellectual quintessence to build a better life, transmit the good ethics of monks and nuns to contribute to upholding the value of compassion and wisdom of Buddhism. in "patriotic service". Therefore, how should monks and nuns know their important role and the social context, the needs of Buddhists and the movement of the righteous wheel in modern times? Therefore, monks and nuns have a sacred duty to spread the Buddha's teachings to Buddhists and people, in order to benefit the majority and for themselves to be able to build a Buddhist society. for the world today. The Buddha once said: "There is no rank in the same red blood, there is no degree in the same salty tear." In addition, Buddhism also shows the spirit of solidarity and does not distinguish between practitioners and believers, the point of view of Buddhism is "Four groups of initiates", that is, monks, nuns, male Buddhists and female Buddhists. Everyone can practice together, and if anyone has the determination, they can achieve the same results as the Buddha.

Since then, the role of monks and nuns has become more important, in order to fulfill the above goals and tasks, it is necessary to perfect and diversify the most popular means of communication, which is to preach on the courts. high quality and requires multiple courts as well as regular maintenance sessions. Make use of those means to have the highest ability to convey the Buddha's teachings and daily life of Buddhists as well as social life. Therefore, Buddhism needs to adapt and develop in modern life to provide spiritually for mankind, Buddhism is the light of compassion and wisdom. Depending on the impetus of the practical situation are the activities and requirements of the majority of Buddhist followers at the establishment. here is the temple and the monks and nuns. Because of the issues that need to be implemented due to the direct activities of Buddhists and the social community. Monks and nuns have great authority over a temple. Therefore, it is highly proactive and can change the living mechanism very thoroughly and in a timely manner. So over the centuries, people have understood the way and turned to the Buddhadharma because of the publicization of the Patriarchs from many previous generations. You have dedicatedly and wholeheartedly taught sentient beings in the five stagnations of life, so they have turned to the Buddhist path. Unlike some major religions in the world, Buddhism advocates no world organization system and clerical system. This comes from the reason that the Buddha clearly understood the human desire for power, so the Buddha advocated not to assign the authority to manage, but only guide his disciples to rely on the teachings and canon law to maintain and exist according to the sect system. The teachings of Buddhism are many, but they all come from real life, not abstract, metaphysical, dogmatic or forced, not forced, but purely oriented to let people depend on conditions, circumstances, the perception is flexibly applied so that no matter which way one of the 84,000 practices pointed out by the Buddha, one will eventually reach the goal of living a peaceful, prosperous and happy life for each person, family, and friends. society. The basic teachings of Buddhism have two important issues, which are the Law of Dependent Origination and the Four Noble Truths (4 truths). Disseminating the Dharma or spreading the Dharma has become a key and important task of the Vietnamese Buddhist Church in the present and in the future. The main purpose is to spread the teachings of the Buddha, bring peace and liberation to people. Besides, the characteristic of Dharma propagation activities is always flexible, especially associated with the spirit of the contract, the contract of origin, the contract of origin, the contract of time. In each different era, country, and country, monks and nuns must have a suitable method of propagating the Dharma, bringing the religion to life in a reasonable and successful manner. "Today, the human world is being strongly affected by industry 4.0, including Vietnam. Therefore, Buddhism in general and the preaching work in particular still cannot stand aside from the impact of the ongoing modern modern industry. So, what does our preaching industry need to do to adapt, match and respond to industry 4.0?" . Buddhism conceives that things and phenomena in the universe are always in motion and constantly changing according to the law of Creation - Sustainability - Destruction - Voidness (each thing has a process of formation, development and existence for a period of time). time, then change to destruction and finally disappear, like a wave, when it first rises it is called a "city", when it rises to the top it is called a "pillar", when it descends it is called "' destruction", until they disintegrate, they return to "emptiness") and are governed by the law of cause and condition, in which cause is the generating power, the germ to create the result, and the condition is the support and the means. convenient for multiplication and proliferation. Depending on the combination of causes and conditions, different things and phenomena are formed. Whether or not a phenomenon or thing is due to the combination or dissolution of many causes and conditions. Cause and condition are also not natural but it is created by the movement of things, phenomena and the process of merging - dissolving of previous causes - conditions to create new causes - conditions, Buddhism calls that. is the "coincidence of predestined origin". This article is just a few initial thoughts of the author to contribute to orienting the work of dharma preaching in the new era. Of course, this is a big deal, and more in-depth discussions are needed to hope for a clear and in-depth understanding of this industry.

\footnotetext{
${ }^{1}$ Report of the Central Committee for the Promotion of Dharma at the Eighth National Buddhist Congress (2017 - 2022).
} 


\subsubsection{Duties and roles of monks and nuns}

The role and duties of monks and nuns become key in the cause of creating faith in Buddhism, so that people have a good view of Buddhism. On the contrary, it is also the monks and nuns who "break the view" of one of the crimes of discrediting lay Buddhists. Looking at Buddhism is not without. So what should monks and nuns do before the urgent needs of today's society? We realize that the person in charge of being the abbot of a temple is very important, it determines the destiny, survival and development of the local Buddhist establishment. From time immemorial, the decline of Buddhism is not a strong or weak ecclesiastical organization, but rather a monastic establishment with or without monasticism; whether or not to guide Buddhists at home or monastic practice, if there is guidance for lay Buddhists at home and monastic studies, then Buddhism flourishes there; On the contrary, although the monastic establishment has developed in terms of facilities, the pagoda is big, the Buddha's temple is big, and there are no outsiders, but without a dedicated practitioner, Buddhism will decline. So in the Flower Adornment Sutra, the Buddha taught: "The human eye is supreme, the power of the gods and the Dharma is strong" which means that human beings are the best because they can create good things. Monks and nuns today, in addition to their religious service, must have a spiritual life, in order to bring the Buddha's teachings into life. By the method of spreading the Buddha's thought through Buddhist knowledge, we can experience not the language of the text, but by our own experience. This is to bring Buddhism into life, to transform life. Make everyone have a happy and peaceful life. With that, Buddhism really has benefits, if this cannot be shown, the beauty of Buddhist teachings will not have any effect. A teacher who goes to the dharma court must always perfect his "body, speech, and mind." The ancients have a saying: "Victory downloads the way", does not give up but understands reason, "the reason is clear - cause and effect are clear".

\subsubsection{The mission of preaching the Dharma of monks and nuns}

Strengthening faith in the righteous Dharma and awareness of the righteous Dharma for Buddhists; raise the level of Buddhism and the ideal of liberation for Buddhist followers; create attraction to increase the number of Buddhist followers and expand the influence of Buddhism on society.

Direct subjects such as fixed training monasteries such as monasteries of eight quan men, Buddhist recitation courses, peaceful one-day retreats, youth resource retreats, etc., fixed periodical lectures at schools lecture halls of the church, lectures organized by temples regularly and irregularly, lectures on summer retreat courses, abbot training courses, and Dharma propagation training courses, recently Ban Hoang Phap Trung The central government planned to open a Dharma training course at Bai Dinh pagoda in Ninh Binh, but because of the complicated development of the Covid 19 epidemic, the Central Department of Dharma propaganda combined with the Central Committee of the Vietnam Buddhist Sangha to organize online for a month. from July 13 to August 13, 2021 with 26 topics of professional content preaching 4.0.

Indirect objects are non-Buddhists and Buddhists have little opportunity to hear the lecture. In addition, an extremely important audience is the Buddhist youth class. There should be a model and program to spread the Dharma among young Buddhists, providing them with skills and art to live happily as well as an awareness of the true value of human life, in the spirit of Buddhism. .

From time immemorial, the Patriarchs have taught: "Buddhist Dharma is wise, due to the aging of the Sangha; Zen Buddhism flourishes, because the Vietnamese dan develops the mind"

\subsection{Practical application of the propagation of the Dharma}

To propagate the Dharma, or to be more specific, to propagate the Dharma, a preacher is anyone who makes others understand the Buddhadharma correctly, regardless of whether monastic or layperson. It is the large number of lay people who contribute to the work of spreading the Dharma that will make the Buddha Dharma come into life more effectively. Dissemination of the Dharma is a typical characteristic of a Buddhist disciple, and anyone who does not have the spirit of preaching the Dharma is not a true disciple of the Buddha. The main purpose of preaching the Dharma since the time of the Buddha was to benefit all sentient beings. Therefore, the preaching of the Dharma is understood with a broader and deeper meaning, not just limited to preaching. The Buddha converted living beings not because he wanted to attract many followers to follow and worship him, but his main purpose was how people could understand and apply the Buddhadharma in life to relieve suffering., get peace and happiness. Right in this world.

Traditional methods of preaching the Dharma: In the past, the Buddha and his disciples went to beg for alms every morning, the top was to ask the Buddha's teachings, the bottom was to be sown in the field of happiness and that It is also a form of legal propaganda. This form was very effective and practical at that time. Later, according to the development process of society, and the development needs of facilities, technology and technology are more and more modern, the means to serve the preaching work are also diversified accordingly. We can mention the methods of preaching the Dharma such as: "Chanting, preaching and performing rituals"1: Chanting the sutras is not for the purpose of letting Buddhists imbibe the Dharma; preaching is to explain the

\footnotetext{
${ }^{1}$ The Conference on Propaganda of the Central Committee for Propaganda in Nha Trang, Khanh Hoa 2018.
} 
profound meaning of the Buddha's teachings in the Tripitaka; rituals in the life of lay people such as funerals, weddings, and anniversaries should have the evidence of monks and nuns to chant and pray, which is also an effective way of spreading the Dharma; Lecture; writing books, publishing classics, publishing lecture tapes; Organizing retreats at monasteries, guiding Buddhists to practice...

Promote Buddhist communication as a channel for spreading the Dharma, develop charitable and social activities, educate and make efforts to promote the good application of social networks in propagating and conveying the good image of the Sangha. Nuns actively participate in activities of disseminating the Dharma for profit, social work, good images and the spirit of Compassion - Wisdom to the community and society. Buddhist Media in collaboration with the Central Committee of the Publication of Dharma aims to make every Buddhist using a mobile audio-visual device, a smartphone become a media member of Buddhism, and every Buddhist is a Dharma preacher. member of the digital technology era in which the industrial revolution 4.0 is taking place.

Propagation of the Dharma is the daily work of all those who carry out the monastic life of the holy life. The Buddha himself encouraged his disciples to be active in the propagation of the Dharma.

With the duties of monks and nuns in the church, especially the teacher, where direct communication with the masses of Buddhists is diverse in society, there are many different ways to propagate the religion. "Dependent transformation" is not necessarily "rigid" according to a certain pattern, because the Buddhadharma is "indeterminate". But saying that does not mean that despite all the ethical rules of the monastic, what we do must be deliberate and bring a sincere heart to everyone, otherwise it will become unethical to hurt people. hurt his religion but also affected his own career.

\subsection{Solution on the propagation of the Dharma of monks and nuns.}

The most necessary thing in monks and nuns is in the heart of virtue. These are two very important aspects that before being entrusted with the sacred task of preserving the church foundation, teaching people to return to the righteous dharma, overcoming suffering, and living freely in the midst of the life that the priest The abbot has made a vow through daily activities, the abbot must be able to show the manners of a true monk, solve everything with a spiritual mind, with the virtue of a person who practices and cultivates. . When we come into contact with such a teacher, we will feel the energy of peace and naturally transform positive energy.

The Department of Information - Communication and the Department of Public Affairs have a close mutual relationship with each other, repelling bad information, distorting in the form of light, where the darkness recedes, where the wisdom goes. Ignorance disappears there, fragrant flowers encroach on weeds. Where there is love, hatred and jealousy will be reduced, peace will bloom, gradually forming a civilized and humane society. "The highlight of the Buddhist press today is to clarify religious issues in social life, creating conditions for those who are concerned with faith and the Buddha's grace to have a more correct and objective view. about religion. This press also promotes national consciousness and traditions, contributing to the building of great national unity. In addition, contributing a significant part in promoting and orienting the building of a traditional cultural lifestyle and national morality. ${ }^{1}$

Buddhism is developed, Information-Communication and Dharma are developed digitally, the young generation are potential factors, proficient in using technology, internet, etc. Buddhist activities such as Buddhist family activities, summer retreats, courses and trainings on life values according to Buddhist ethics specifically for students, intellectuals, young workers who have been and are having positive values. , promoting an increasingly civilized and progressive society and at the same time contributing to the lasting development of Buddhism. "To achieve the highest efficiency, communication needs to be conducted on all three channels: the official press, the Buddhist website and the social network. In particular, monks and nuns need to strengthen the exploitation of the power of social networks to reach out to young people, helping them better understand Buddhism, about Buddhism in Vietnam and about the Buddhist children around them. From there, attract young people to orthodox Buddhism, towards diligent practice, practice of Body, cultivation of speech, and cultivation of Italy in order to build a peaceful and sustainable life. ${ }^{2}$

From the general situation presented above, it is also a good opportunity if Buddhists know how to make efforts to apply technology to perform the task of spreading the Dharma for profit, it will bring positivity about the good and the spirit. Compassion-Wisdom, altruism for society and the community, netizens. That is also how we carry out the Buddha's teachings on the cleverness of the Gong, one of the five subjects that Buddhists need to master. "In the age of internet citizens, digital media, anyone can be a media. But for effective communication, it is necessary for the community to join hands and contribute, and above all, a really effective,

\footnotetext{
${ }^{1}$ Arguing about the profession of Buddhist journalism, author: Thai Quang, posted on the Buddhist page at the address: http://nguoiphattu.com/van-hoa/van-hoc-tuy-but/8954-tan-man-ve-nghe-lam-bao-phat-giao.html.

${ }^{2}$ The role of media in guiding young people to Buddhism. Author HT posted on the Vietnamese Buddhist Culture page, at the address:http://vanhoaphatgiaovietnam.net/tin-tuc/single-post/vai-tro-ca-truyn-thong-trong-vic-hng-gii-tr-ti-o-pht-561】
} 
organized and professional association is what the Buddhist community expects. ". Before the valuable opportunity for Information-Communication work that is still open, it is necessary to urgently deploy and implement it in the most effective, useful and beneficial way for the masses. Therefore, the 8th National Buddhist Congress (2017-2022) has set out the program of orientation for Buddhist activities at point 8 which is "Promoting Buddhist communication as a channel for disseminating the Dharma".

\subsubsection{Assessing the current status of Buddhist communication activities ${ }^{1}$}

\section{Advantage:}

Objective: Buddhism with a history of over two thousand years accompanying the nation with the spirit of Ho Quoc and An Dan, currently has over 18,000 worshiping establishments and nearly 54,000 monks. Over $50 \%$ of the population has faith and sympathy with Buddhism. In which, there is a large number of participants using Websites and social networks as communication for individuals or worshiping establishments.

Structure: The Department of Information and Communications is one of 13 departments and institutes of the Central Church and is also a department of the Church at provincial and district levels, with an organizational system from central to district level. Young monks and nuns are enthusiastic about Buddhist communication.

Individuals: There are quite a few monks who are able to preach and volunteer to do media work to spread the Dharma by mobilizing funds to serve Buddhist communication. Buddhists who use social networks as communication all have the same kind heart that they want to spread the Buddha's teachings and do social work humanitarian charity for the benefit of society and the community.

\section{Difficult:}

About personnel: There are too few monks involved in Buddhist communication activities, spontaneous, lacking expertise, lack of professionalism, not equipped with technical skills and professional skills. As for lay people with expertise in communication, they have limited knowledge of Buddhism and vice versa.

Regarding content: There is no consensus on specific regulations, regulations, laws as well as management and leadership, so information-communication activities have personal content, communication spontaneity. without purpose and focus, sometimes even posting a lot of content that is not in line with the Buddhist teachings and ideas, which are subjective and personal inference.

Regarding the work of education and training: Buddhist activities and Dharma propagation through modern media is still a strange concept to the seniors. "Most of the venerable ones do not like to introduce, or even write about, your Buddhist achievements. Some are very afraid that the writer will misquote or paraphrase the story, which may damage credibility and morality. This mentality has caused many difficulties for media workers". ${ }^{2}$ Young monks and nuns working in professional communication are not encouraged and created favorable conditions in learning and improving their worldly knowledge and knowledge related to communication at an advanced level, belonging to the mainstream training system. long-term rule.

About equipment: Technical communication equipment has not been invested and synchronized. Funding has not been attracted from interested Buddhists to support and donate to ensure sufficient equipment to operate.

\subsection{2 . Opportunity to propagate Dharma for monks and nuns}

Policy: Being included in the Resolution of the 8th National Buddhist Congress (2017-2022) on the direction of activities at Point 8 is a favorable opportunity to strongly develop Buddhist communication from the Central to the Church. district.

Building a modern Hoang Phap system: Information technology, high-speed transmission lines and social networks are in a strong development stage. At the same time, the industrial revolution 4.0, which brings digital technology, has facilitated the transmission and posting of still and moving images of digital videos of Buddhist activities and Dharma propagation. Every Buddhist who uses modern audio-visual mobile devices and smartphones is a media member of Buddhism, a dharma teacher of the digital age. Widely and extensively developed, with excellent efficiency and quality: There are a large number of monks, nuns, and Buddhists using smartphones and audio-visual devices with social networking applications and consciously voluntarily propagate images of Buddhist activities, social work - humanitarian charity of monks, nuns, Buddhists and Church

\footnotetext{
${ }^{1}$ According to the SWOT model: strengths, weaknesses, opportunities and threats.

2 The situation and solutions to improve the effectiveness of Buddhist communication in the current period author: Venerable Chau Hoai Thai posted on the website of the Central Committee of Information and Communications of the Church at the address:http://m.phatgiao.org.vn/doi-song/201310/Tam-su-cua-su-co-mot-tay-quay-phim-mot-tay-chup-anh-12367/van-dequan-tam/201310/Bai-2-Thuc-trang-va-giai-phap-nang-cao-chat-luongtruyen-thong-Phat-giao-trong-giai-doan-hien-nay-
} 
organizations at all levels. To uphold the values of Compassion - Wisdom, selflessness, selflessness, peace and harmony of Buddhism in the cause of religious service and patriotism.

\subsubsection{Dangers and challenges of monks and nuns' preaching}

Negative effects of social media: In addition to favorable development, social networks are being intentionally abused by a small number of people in a negative way to exploit the negative side of information to gain views. sentence views) implement its own intent. Since then, it has led to the loss of public order and security, especially for young people when participating in social networks and the Internet, and also affects the belief and reputation of Buddhism. "According to a Georgia State College survey titled "The Negative Effects of Social Media on Children and Teens" released this year, U.S. youth age 8 up to 18 have been on social media sites for 45 minutes to 10 hours a day. $51 \%$ of children said they had been bullied by a website, while $49 \%$ of children said they had harassed others online. Meanwhile, according to the same survey, 72 percent of parents are concerned that their children will discover inappropriate information online.". ${ }^{1}$

"Since the advent of social media, communication crises have spread rapidly. If in the past, information almost depended on official newspapers, or discussed indirectly through the pen of reporters, now news spreads every second, every minute through each individual channel. individuals, communities on social networks" 2 .

"Today's online media, due to its spontaneity, lack of objective awareness, and not being sanctioned by the constitution, so it spreads misinformation without knowing right or wrong, regardless of the consequences. Many families are separated because of inaccurate and unverified information". 3

Solution 3: Build and train every Buddhist to become a Dharma practitioner using smartphones to develop Buddhist communication as a channel for spreading Dharma

Build applications to watch Buddhist activities, listen to lectures on smart mobile phones and audiovisual devices.

The Central Committee of Information and Communications in collaboration with the Central Committee for Dissemination of the Law and the Central Committee for Guidance for Buddhists deploys to lecturers who have a sense of propaganda and active advocacy to integrate it in the lectures. From there, for Buddhists to consciously apply tools to watch and listen to programs on Buddhist activities and lectures on entertainment media, modern audio-visual equipment and smartphones, with Regularly update sharing about Website and fanpage on personal page wall to introduce to friends and online community.

"In an era when the media dominates all the activities of every individual, every Buddhist, monk, and nun, we need to be aware of and use the media to support the preaching of the Dharma and contribute to the cause. part of building and developing people and society so that everyone can live well and live well. Currently, there are many problems in society: corruption, negative thinking, group interests, irresponsibility, fighting, evils... The nation is in dire need of peace, in great need of Compassion - Compassion - Hy - Discharge. No one but us can do this. No other religion but Buddhism can solve these problems". ${ }^{4}$

In fact, if the monks and nuns had only focused on studying the scriptures and practicing the Dharma, they would have been able to teach many people. Because after all, the job of the monks and nuns is to preserve the life of the Buddhadharma, so "meditation" is the spiritual "food" of the monks and nuns. The masses coming to the temple are necessary for them. It is not about discussing worldly affairs or politics but studying and researching and collecting the Buddha's teachings. Therefore, if there is no definite use of the Buddhist teachings, it will be a big omission to consider one's mission and life's land difficult to complete. This is the most effective way of propagating the Dharma of the monks, nuns and monks.

Application of Information Technology in Dharma propaganda activities in the current period. In the Lotus Sutra, the Buddha taught: "The purpose of the Buddha's birth is to help sentient beings understand and see

\footnotetext{
${ }^{1}$ Thinking about the media and Buddhism Author: Huynh Kim Quang posted on the Lotus Library page the article address: https://thuvienhoasen.org/a23205/nghi-ve-truyen-thong-va-phat-giao

2 Handling media crisis in the spirit of Buddhism Author: Xuan Phuong posted on Enlightenment Online at: http://giacngo.vn/mobile/default.aspx?CategoryID=110\&GroupID=1101\&ContentID=5FC4D9

${ }^{3}$ Buddhists face the reality of the media reporting negative news about Buddhism. Author: Minh Man posted on the page: Buddhists. post address: http://nguoiphattu.com/phat-phap/su-kien-van-de/8186-nguoi-phat-tu-truoc-thuc-trang-truyen-thongdua-tin-tieu-cuc-ve-phat-giao.html

${ }^{4}$ Thinking about Buddhist Communication, Author: Thien Duc - Nguyen Manh Hung, posted on the Lotus Library page at: https://thuvienhoasen.org/a25156/nghi-ve-truyen-thong-phat-giao
} 
the Buddha"1. Obeying the teachings, we Buddha's children follow the Master's vows, bring his teachings to the masses, help people understand and understand the Buddha to live a happy, happy life and move forward. complete liberation from the cycle of birth and death. That is the mission of propagating the beneficial Dharma that the Patriarchs have handed down for more than 2000 years.

Today, especially in the era of the 4.0 industrial revolution, the Vietnamese Buddhist Church always affirms the importance of Dharma propaganda through the Resolution of the Eighth National Buddhist Delegate Congress: "Renovation, being creative in the cause of propagating the Dharma, in the method of guiding Buddhists... And promoting Buddhist communication as a channel for spreading the Dharma". ${ }^{2}$ Implementing the Resolution of the VIII National Congress, the Central Committee for Propaganda advocates promoting the preaching work in 2018 and recent years through digital means and has achieved many encouraging results, which have been approved by the Church. as well as society recognized and appreciated.

\subsubsection{Difficulties and inadequacies in the previous preaching work and the results achieved when applying information technology to preaching activities}

In the era of Indian society when the Buddha was alive, the work of preaching the Dharma was simple but extremely effective. Simply because there is only one form where the preacher meets the audience directly, usually not much. The effect is because the people who preach the Dharma are the enlightened Arahants. In addition to your preaching ability, you also have a very high ability to move the masses. But after the Buddha entered Nirvana, the later the preaching became more and more difficult because of many obstacles, due to the increasing number of listeners but limited means. For example, in Vietnam: until the beginning of the twentieth century, printing technology in our country was still quite rare, mainly by hand-printing with woodblocks, so it was not easy to print a sutra. Therefore, Buddhist scriptures are very rare, the temple does not have enough woodblock scriptures to provide monks and nuns to study and study, let alone disseminate to the masses. The preaching of the Dharma also revolves around the direct form between the speaker and the listener.

From the end of the twentieth century onward, the situation improved. Printing technology is developing and popularizing more and more, so scriptures can be printed more easily and are more and more abundant; Audio-visual media such as newspapers, radio, cassette tapes, and other types of radio equipment were born to help promoters more convenient in their work. However, the extent is still limited compared to today. In the last years of the twentieth century and into the twenty-first century, there was an explosion of digital technology with many medias such as the Internet, email, social networks Facebook, Twitter, Zalo, Youtube, etc. and search engines such as: Google, Yahoo... make the world closer together and all information come together quickly. All of the above together create an era of digital technology in the field of communication in our country.

Applying information technology to preaching is an important method that has been applied over the past 20 years. Digital technology has given wings to the Buddhist scriptures to fly thousands of miles away to reach all who are interested in learning. Thanks to information technology, it is easy for Buddhists to listen to the Dharma and grasp information about the Church's Buddhist activities throughout the country. Thanks to information technology, Buddhist culture spread quickly to all walks of life. Also thanks to the application of information technology, Buddhism can quickly access new perspectives, positive or negative opinions from society to be able to assert their views, direct public opinion or feedback. what is not exactly - something we could hardly do before. After a period of applying information technology to preaching, we have achieved some remarkable results. Websites of Churches at all levels and of monasteries throughout the country develop rapidly and strongly in both quantity and quality. On these websites, there are quite enough and rich articles, Buddhist information, articles expressing the views of Buddhism, etc., to satisfy all those who want to learn about Buddhism or want to learn. Buddha or need to capture information about Buddhist activities. Social networking sites such as: Facebook, Twitter, Zalo, Youtube of individuals, especially some famous professors in the country as well as abroad, like brilliant flowers of all colors and fragrances that spread the What is the most quintessential of the Buddhadharma everywhere. The Vietnam Buddhist Sangha established the Information and Communication Department in 2012 at the VII Congress in the VIII term (2017-2022), the 2nd Office of the Central Church's Central Committee established the Information and Propaganda Team, on the 28th. On March 3, 2018 launched the Information channel - Online Buddhist Live TV channel under the 2nd Office of the Central Church, to promptly reflect all aspects of the Vietnam Buddhist Sangha's activities through the forms of newspapers. Reading, the Board of Directors of the Church at all levels from newspapers, stills and videos have been updated daily on social networking sites. Recently, the Information and Propaganda Department of Office 2 has promptly had video reports to reflect on some issues related to Buddhist beliefs that are spreading in social life. Especially the Video Bridge on the occasion of the Buddha's Birthday, the 2562 - DL 2018 has blown a new wind in the Buddhist activities of the whole country. Information Channel - Live TV channel of Buddhism

\footnotetext{
${ }^{1}$ The Lotus Sutra, translated by Venerable Tri Tinh, Religion Publishing House

2 Proceedings of the National Buddhist Delegate Congress term (2017-2022).Religious Publishing House.
} 
Online and Western Buddhism, In particular, the launch of an application application installed on the phone to view news of Buddhist activities, listen to Dharma lectures on phones and mobile audio-visual devices is a clear example of the application. Information technology in legal work. Each Buddhist news that has just been posted immediately has tens of thousands to hundreds of thousands of views, creating a good effect in Buddhist activities throughout the country, creating the excitement of monks and nuns, Buddhists inside and outside. Vietnam and overseas Buddhist associations, because it is possible to continuously update news of Buddhist activities of Vietnamese Buddhism as well as to watch or listen to live Dharma lectures through online channels of Buddhism, Buddhism Online. , Butta online...

It can be said that the application of information technology to the propagation of the Dharma is an inevitable trend of Dharma propagation in particular and other activities of the Vietnam Buddhist Sangha as well as the whole society. In fact, the past time has proven its effectiveness. However, in the face of the rapid and strong development of information technology, the Central Propaganda Department and many other departments of the Church need to upgrade existing applications and continue to invest in necessary equipment. necessary to keep up with the development of science and technology and continue to invest in some forms of application, and at the same time improve the level of transmission content and utilities to improve the effectiveness of propaganda activities in the community. next time.

\subsubsection{Some solutions to apply information technology in propaganda work \\ Nurturing human resources}

Identifying people as one of the leading factors determining the success of applying information technology to the work of Dharma propagation, therefore, the Buddhist Church at all levels should pay special attention to fostering and raising awareness. high level of informatics and information technology application skills for the team of people working in communication and propaganda work, so that they can have a professional team to do this job well. This is the factor, the most important solution, determining the success or failure of all activities.

\section{Raising awareness for monks and nuns}

Promote propaganda for monks and nuns to clearly see the effectiveness and indispensable requirements of information technology application in reforming teaching methods through many forms such as: Deploying point 8 of the Operational Orientation Buddhist affairs of the VIII National Buddhist Delegate Congress, term 2017-2022 and guiding documents of the Central Church on the work of digitizing Church administration, communication and information technology application in the Church. Buddhist activities; through monthly Sangha meetings and professional training courses for abbots, training courses on teaching the Dharma, fostering secretarial and office skills for monks and nuns.

In particular, for successful implementation, first of all, the religious leaders of the Buddhist Church at all levels must be fully aware of the role and importance of applying information technology in preaching.

Improve information technology and information technology application skills for monks and nuns. Building a team of monks and nuns

Fostering information technology skills and information technology application for members of the Information and Communication Department and the Department of Public Affairs.

Each monastery appoints a monk and nun to receive professional training. Since then, a core team has been formed in applying information technology to preaching work.

The Central Committee for Propaganda has developed the project "Application of information technology in propaganda work for the 2017-2022 term. After the Seminar "Dharma Dissemination in the New Era" was held in Khanh Hoa from September 27-30, 2018, the Central Committee for Dissemination of the Law will send a delegation to all provinces and cities to train and share experiences to all. all the venerables of the Ban Hoang Phap in the provinces and cities in order to be timely and competent, and to apply information technology skills in the teaching of the Dharma. In order to achieve the results of the spirit of the Resolution of the Eighth National Buddhist Congress stated: "Innovation and creativity in the cause of propagating the Dharma, in the method of guiding Buddhists... And promoting Buddhist communication teaching as a channel to propagate the Dharma". At the same time, towards each lecturer of the Department of Public Affairs at the provincial, city and central levels, they have the capacity and skills to apply information technology and social networking sites such as Facebook, Twitter, Youtube, wechat, Zalo, ... In the work of preaching, preaching is directed to every Buddhist, the Dharma preacher is an official who propagates the Dharma on social networks through mobile audio-visual devices and smartphones.

\section{Open regular refresher courses on skills}

Organize training courses on computer skills and professional support software. These training classes are organized in the form of mutual help and exchange, focusing mainly on the skills that monks and nuns need to use in the process of teaching, starting from the simplest skills such as how to investigate Research and find information, how to convert fonts, how to use some media such as projectors, camcorders, photography, steps to compose a presentation, common software and skills use social media,... 
Currently, the Central Buddhist Church as well as many localities still lack many equipments to serve the work of preaching by information technology. Therefore, in the near future, leaders of the Buddhist Church at all levels should pay attention to investing in information technology equipment to serve the work of teaching more effectively.

It can be said that, thanks to the application of information technology in the propagation of the Dharma, over the past time, Buddhism in Vietnam has developed a lot in quantity and quality. Buddhists have more and more opportunities to approach the Buddha's teachings, thereby strengthening their belief in the Three Jewels.

The Buddhist Churches at all levels need to pay more attention to investing in people and equipment to take advantage of the superiority of digital technology in preaching the Dharma in particular, and Buddhist communication activities in general, in order to keep up. the development of society in the new era where the 4.0 revolution is taking place in all parts of the country.

\section{Conclusion}

Communication plays a very important role in today's social development. Communication is a continuous process of exchanging or sharing information, feelings, and skills in order to create a connection with each other leading to change in behavior and perception.

There are many different means of mass communication, the most popular are Radio, Television, Press and Internet, in the era of information technology explosion, mass communication plays an even more important role in people's lives. social life. Especially in recent years, the technology of live television (Live stream) on social networking sites such as Facebook, Youtube... has created a new development in digital video communication and 4G, 5G sim plus High-speed transmission has made it convenient to broadcast live events anytime, anywhere, which has had a strong impact on society on the impact of modern mobile audio-visual equipment and smartphones. This is a very favorable time to form a digital TV channel to broadcast live and post on Fanpage of Facebook, Youtube, Youku and other social networking sites about Dharma propagation programs, Buddhist activities, etc. charity, social security and Buddhist education... "The presence of Buddhist forms and terms in life has not been considered the presence of Buddhism in life: It is when, people We see the essence of Buddhism pervading all activities of life as a vital reality"

This is also an opportunity to develop and implement well the 8th point in the direction of Buddhist activities of the VIII National Buddhist Congress (2017-2022) which was successfully held from 19-22 May. November 2017 in Hanoi with the content: "Promoting Buddhist communication as a channel for spreading the Dharma and transferring Buddhist activities into social life in order to uphold the values of Compassion and Wisdom of Buddhism., a good image of monks, nuns, Buddhists and Church organizations at all levels in the cause of patriotic service, construction and defense of the Socialist Vietnamese Fatherland".

Finally, I want to summarize that, the industrial revolution 4.0 is a trend, a great progress of mankind that no one can reverse. We, the monks and nuns with the responsibility of holding the torch of the Dharma, with the wisdom of the Buddha's son and the spirit of contract, contract, land, and time, need to learn, grasp and take advantage of the achievements of life. This revolution to apply in the field of life-saving propaganda. By doing so, we will effectively propagate the wonderful teachings of the Buddha in the civilized age with the advanced achievements of science and technology.

However, with the experience of my forebears, I would like to emphasize that no matter how human civilization develops, no matter how our society changes, the practice of cultivating the Three Noble Truths, The "Precept-Concentration-Wisdom" aspiration to save birth and the path to liberation and enlightenment is still the end for each person, for Buddhist monks and nuns as well as for the whole society. Therefore, trying to grasp 4.0 technology to apply in the mission of preaching the Dharma, but we still do not forget to promote the core values, the quintessence of the Buddha's living teachings. The source of peaceful energy in body and mind, a wonderful wisdom, an selfless understanding of selflessness, tolerant of all dharmas, helping people to be peaceful and happy, transforming afflictions, getting out of suffering, samsara birth and death, and helping people have a happy and peaceful life right in this world, it is also a part of repaying the Buddha's gratitude. Praying for the blessings of the Three Jewels to bless the world for peace and happiness, for Vietnam to be prosperous, for the Buddhist Church of Vietnam to be more and more dignified in the hearts of the nation, for all people to be happy.

1 Buddhism in the Doi Moi Era. Author Ngoc Chon, posted on Buddhism Today article address:http://www.daophatngaynay.com/vn/phat-phap/buoc-dau-hoc-phat/dd-dao-phat/4795-Dao-Phat-Trong-Thoi-Ky-DoiMoi.html.com 


\section{REFERENCES}

1. Report of the Central Committee for Propaganda at the National Buddhist Congress VIII term (2017 - 2022).

2. Hoa Nghiem Sutra, translated by Most Venerable Tri Tinh, Religious Publishing House.

3. The Conference on Propaganda of the Central Committee for Propaganda in Nha Trang, Khanh Hoa 2018.

4. Arguing about journalism, author: Thai Quang, posted on the page of Buddhists at the address:http:/nguoiphattu.com/van-hoa/van-hoc-tuy-but/8954-tan-man-ve-nghe-lam-bao-phatgiao.html

5. Where is Buddhist media standing? Author: Sister Co posted on the website of the Central Committee of Information and Communications, PhatGiao.org. Post address:http://phatgiao.org.vn/van-de-quantam/201310/Bai-2-Thuc-trang-va-giai-phap-nang-cao-chat-luongtruyen-thong-Phat-giao-trong-giaidoan-hien-nay-12254/van-de-quan-tam/201302/Truyen-thong-Phat-giao-dang-dung-o-dau-9588/

6. Thinking about media and Buddhism Author: Huynh Kim Quang posted on the Lotus Library page the article address:https://thuvienhoasen.org/a23205/nghi-ve-truyen-thong-va-phat-giao.

7. Buddhists face the reality of the media reporting negative news about Buddhism. Author: Minh Man posted on the page: Buddhists. Post address: http://nguoiphattu.com/phat-phap/su-kien-van-de/8186-nguoiphat-tu-truoc-thuc-trang-truyen-thong-dua-tin-tieu-cuc-ve-phat-giao.html

8. The Lotus Sutra, translated by Most Venerable Tri Tinh, Religious Publishing House

9. Buddhism During the Doi Moi Era. Author Ngoc Chon, posted on Buddhism Today article,address:http://www.daophatngaynay.com/vn/phat-phap/buoc-dau-hoc phat/dd-dao-phat/4795Dao-Phat-Trong-Thoi-Ky-Doi-Moi.html.com 